\title{
Editorial
}

\section{Avoiding plagiarism in academic writing}

\section{Apurb Sharma}

\section{Nepal Mediciti Hospital, Sainbu, Bhaisepati, 44700, Lalitpur, Nepal}

\section{Corresponding Author:}

Apurb Sharma, MD

(DORCID iD http://orcid.org/0000-0002-1655-5997

Executive Editor, JSAN

Head, Department of Anaesthesia and Pain Management

Nepal Mediciti Hospital, Sainbu, Bhaisepati, 44700, Lalitpur, Nepal

Email: apurbsharma1976@gmail.com (c) Authors retain copyright and grant the journal right of first publication with the work simultaneously licensed under Creative Commons Attribution License CC - BY 4.0 that allows others to share the work with an acknowledgement of the work's authorship and initial publication in this journal.

How to cite this article: Sharma A. Avoiding plagiarism in academic writing. Journal of Society of Anesthesiologists of Nepal (JSAN) 2017;4(2):47-48.

Recently, our national newspapers were filled with sensational news on plagiarism. The culprit article was retracted by the journal and the authors were blacklisted for scientific misconduct.

With the rising pressure to publish scientific articles for academic promotion and recognition, the chances of submitting a plagiarized article for publication is extremely high. However, a completely plagiarized text as seen in the newspaper is rare. Most of the times authors tend to copy one sentence from a paper and another sentence from a similar paper to express their ideas as it is extremely easy to copy and paste from the internet. Sometimes, authors think that citing the original text actually removes the chance of one's text being called plagiarized. So, what actually at the Journal of Society of Anesthesiologists of Nepal (JSAN) is considered to be plagiarism?
Plagiarism means copying someone else's ideas or texts; put it forward as original and present it as one's own. JSAN has a predefined plagiarism policy which states that the authors should ensure that they have written entirely original works in their own words and if the authors have used the work or words of others, that should be appropriately cited or quoted. However, copying the text of key areas like the introduction, discussion and conclusion might create suspicion on plagiarism regardless of citation provided. We are generally suspicious when two consecutive sentences are copied from a source. If three or more consecutive sentences are copied, then it definitely is plagiarism. JSAN makes use of the ithenticate software for plagiarism check with the courtesy of the International network for the availability of scientific publications (INASP).

Most of the articles that were declined publication in JSAN on the ground of plagiarism were based on peer reviewers' comments and the data of 
ithenticate software. Most of the articles had paragraphs from different papers compiled in their paper especially in the introduction and discussion part. However, many corresponding authors thought that they had cited the original literature, and hence they did not consider that as plagiarism. The editorial team of JSAN believes that such act of copying a whole paragraph is plagiarism. Such articles will not be accepted for publication regardless of their original scientific information. Sometimes, authors use the text of their previous articles on a similar topic and land up doing selfplagiarism.

There are a lot of books and articles on how to avoid plagiarism. Based on the literature and type of plagiarism in articles submitted to JSAN, the editorial board suggests some points that help authors avoid plagiarism.

Most of the times authors tend to lose the record of sources and forget to cite others work. Use of software like Endnote, Mendeley, RefWorks or reference manager is helpful. The software should be used early at the time of literature review. Quotation marks are useful when you use others text to support your argument. Writing others ideas in your own language is important and they should receive proper attribution. Authors should avoid using unnecessary and irrelevant information from other articles. While submitting tables and figures from a previously published article, authors should acquire proper permission. Authors need to cite their previously published work to avoid selfplagiarism. The length of the text is generally long at the completion of the preliminary draft. The authors should then try to shorten the text and write in their own words. In the end, they should review the text for appropriate source citations.

Non-native English speakers like us have several limitations in writing and tend to use sentences from similar previously published papers. Plagiarism is considered fraud even when done unknowingly or accidentally. After all, breaking the laws unintentionally is still considered a criminal act. The society of Anesthesiologists of Nepal started publishing the journal to help local and regional authors. ${ }^{1} \quad$ The publishers recognize that anesthesiologists, intensivists and pain practitioners of Nepal and other developing countries can make important scientific contributions to the medical literature. A passionate answer to one's research question in one's own words is the best way to avoid plagiarism.

Conflict of Interests: Dr Sharma is the executive editor of the Journal of Society of Anesthesiologists of Nepal and has nothing to disclose.

\section{References}

1. Sharma A, Pradhan B. Do we really need a new journal? Journal of Society of Anesthesiologists of Nepal. 2014 Mar 1;1(1):1-2. 